\title{
Strategic Framework of Professional Preparation of Trainees in the Field of Security and Defense, Professional Field of Administration and Management - Socio-Demographic and Educational Aspects
}

Original article

Received: 2021-03-09

Revised: 2021-03-23

Accepted: 2021-06-27

Final review: 2021-03-23

\section{Peer review:}

Double blind

\section{Keywords:}

professional preparation, security and defense, military training, administration and management Socio-demographic and educational aspects

This work is licensed under the Creative Commons AttributionNonCommercial-NoDerivatives 4.0 License

\author{
Boryana Varbanova ${ }^{1, A, B}$ \\ ORCID (iD 0000-0001-8941-2316
}

\author{
Elitsa Petrova ${ }^{1}, \mathrm{C}-\mathrm{F}$ \\ ORCID (1D 0000-0002-8291-7108 \\ ${ }^{1}$ Vasil Levski National Military University, Bulgaria
}

A - Research concept and design, B - Collection and/or assembly of data,

C - Data analysis and interpretation, D - Writing the article,

E - Critical revision of the article, F - Final approval of article

\begin{abstract}
Objectives: To clarify the factors that influence the individual's career orientation and professional fulfillment of cadets, which can be deeply personal as well as dictated and conditioned by the external environment.
\end{abstract}

Methods: A Survey of trainee opinion in the professional field of Administration and Management at the National Military University.

Results: The study focuses on the socio-demographic and educational aspects of the need for training in the professional field of Administration and Management, following the example of the Department of Security Logistics, National Military University, Bulgaria. Respondents in the survey were 164 trainees from 5 consecutive years of study in the Bachelor's degree program in the professional field of "Military Affairs".

Conclusions: It is necessary to direct its efforts to recruit future trainees mainly from secondary schools, vocational high schools of economics and vocational high schools of mechanical and electrical engineering, trainees from families with low- and middle-income, trainees with strong personal motivation to practice the military profession, trainees who achieve high results in their education. The information channels for accessing better, timely and reliable information about the applying process and training at the Vasil Levski National Military University should be expanded using social networks, media and more information campaigns in schools. To a large extent, parental opinion about trainees' choice of the military profession, also has an influence which was found to be very positive. 


\section{Introduction}

Security and defense training intertwines different scientific areas in a complex puzzle of knowledge, skills, and abilities, characterized by both strengths and weaknesses. The problems concerning the military-professional training and diagnostics of the career orientation and the professional fulfillment of logistics officers trained at the National Military University have not been a subject of sufficient scientific and scientific-practical analysis; thus, they provoke the necessary scientific curiosity and should be given the necessary scientific and practical-applicable significance by initiating a series of scientific researches in Bulgaria and publications worldwide. In connection with the successful goal achievement of the individual and collective military training, as well as in connection with the successful mastering of the profession of officer, we need to clarify the factors that influence the individual's career orientation and professional fulfillment, which can be deeply personal as well as dictated and conditioned by the external environment.

The army exists and should perform its functions related to the security and defense of the country in a complex economic, political and international environment. The strategic security environment is characterized by high dynamics and growing unpredictability. The changes in it depend on the growing influence of non-military (asymmetric) risks and threats, characteristic of the beginning of the 21st century, analyzed in detail in The National Security Strategy of the Republic of Bulgaria, the National Defense Strategy, and the White Paper on Defense and the Armed Forces. The participation of the Republic of Bulgaria in NATO's collective defense and in EU's Common Security and Defense Policy is a reliable means of protecting its national interests.

This study focuses on the socio-demographic and educational aspects of the need for training in the professional field of Administration and Management, following the example of the Department of Security Logistics, National Military University, Bulgaria. Its aim is to support the formulation and implementation of the current and future educational and research initiatives in the EU and NATO, which are fundamental to the strengthening of international security and act as a natural guarantee of peace and stability in Europe and the world. The successful management of the personnel development aims to ensure that the Armed Forces recruit capable people who have the necessary qualifications and professional experience, considering the needs of both the system and the individual.

A large volume of literature sources was studied to form a questionnaire and methodology for work - more than 50 different sources, as only a small part of them is 
reflected in the references of this article, namely scientific theoretical and practical-applied developments:

- On the issues of professional preparation of trainees in the field of security and defense: (Updated National Security Strategy of the Republic of Bulgaria, 2018), (National Defense Strategy of the Republic of Bulgaria, 2016), (White Paper on Defense and Armed Forces of the Republic of Bulgaria, 2010), (Regulations for application of the Republic of Bulgaria Defence and Armed Forces Act, 2018), (Strategy for development of the system for education and qualification of the personnel servicemen of the Armed Forces of the Republic of Bulgaria, 2006), (Marinov, 2018), (Stoykov, 2018).

- On the issues of training in the field of management and administration and the challenges for young people - (Methodology for monitoring of the classes held at the Vasil Levski National Military University, 2004), (Regulations for admission and study activities at the Vasil Levski National Military University, 2013), (Doncheva, 2017), (Hysa et al., 2020), (Izadi et al., 2020), (Ştefănescu, 2011), (Doncheva, 2014), (Petrova, 2015), (Zegoicea et al., 2013).

- On the issues of education of cadets and officers: (Manolov, 2016), (Varbanova, 2014), (Atanasova-Krasteva, 2012), (Tzvetkov et al., 2015), (Manea et al., 2020), Zhekova, Vyara (2013).

\section{Training in the professional field of Administration and Management at the Vasil Levski National Military University (NMU), Bulgaria}

In the Department of Security Logistics at the Vasil Levski National Military University in the professional field 3.7 'Administration and Management' cadets and students are enrolled in Bachelor's and Master's degree programs in the following specialities: Security Logistics (SL), Bachelor's degree - full-time and part-time studies and Master's degree - parttime study; Economic Logistics (EL); Bachelor's degree - full-time, part-time and distance learning and Master's degree - part-time and distance learning; Business Management (BM) only Master's degree, part-time study.

Structurally the Department of Security Logistics is the leading department for training in the professional field of Administration and Management.

The policy of implementing the relationship between research and training is set out in the National Strategy for Scientific Research, The Strategy for Development of the Academic Staff at the Vasil Levski National Military University, Bulgaria, the Strategy for Scientific Research at the Vasil Levski National Military University, the Strategy for Development of the Department of the Security Logistics and others, where the priorities and goals of the 
research activities have been officially published. The Strategy for Development of the Academic Staff of the Republic of Bulgaria clearly defines one main strategic priority to improve, develop and qualitatively raise the level of military-scientific work and research of the academic staff, to achieve significant creative results and optimize the unity of the educational and research activities.

Strategic goals related to the main priority are:

- Development of stimuli and mechanisms for activating the academic staff's scientific research work.

- Development of a quality management system for the scientific work and research done by the academic staff.

- Establishing forms and mechanisms for achieving unity between educational and scientific work.

- Defining priority scientific directions for the academic staff's development and providing them with modern equipment for scientific research.

The Training Quality Management System (TQMS) ensures the fulfillment of the requirements of the educational standards for periodic analysis and reporting the results related to the teaching methods and the way of assessing trainees' achievements considering their opinion. During the educational process, knowledge and skills are tested through written, oral and automated forms of testing, defined in the curriculum. The scores of tests, term and state exams, and also the thesis defense is analyzed and announced in the monthly, semestral, and annual reports of the departments and the faculty. The results of the educational process are reported as follows: for the university - at the end of the academic year by the head of the university; for the faculty and the department - at the end of each semester by the head of the faculty and the department. An automated information system and specialized subsystems have been created for the faculties, which provide publicly available or accessible for certain users' inquiries about students' success rate in the database.

\section{Survey of trainee opinion in the professional field of Administration and Management at the National Military University, Bulgaria}

In September 2019, a survey of trainee opinion was carried out in the Department of Security Logistics in order to fully identify problem areas and find possible solutions. Respondents in the survey were 164 trainees from 5 consecutive years of study in the Bachelor's degree program in the professional field of 'Military Affairs', specialty Organization and management of tactical units for logistics in accordance with the requirements for the regulated profession of tactical management officer, civilian specialties 
'Security Logistics' and 'Economic logistics'. The survey consisted of 12 questions, the answers to which are presented below.

1. What was your motivation for applying to the Vasil Levski National Military University?

- the information campaign carried out by university representatives $-7 \%$

- university website $-4 \%$

- parents $-21 \%$

- friends $-13 \%$

- university lecturers $-2 \%$

- media $-0 \%$

- my personal desire to practise a military profession - $38 \%$

- the strength of military organizational culture, incl. values, norms, symbols, rules, and traditions $-15 \%$

The data analysis shows that personal desire to practise a military profession was the leading motivation for trainees' choice to apply to the Vasil Levski National Military University, followed by parental advice and the importance of military organizational culture, incl. values, norms, symbols, rules, and traditions.

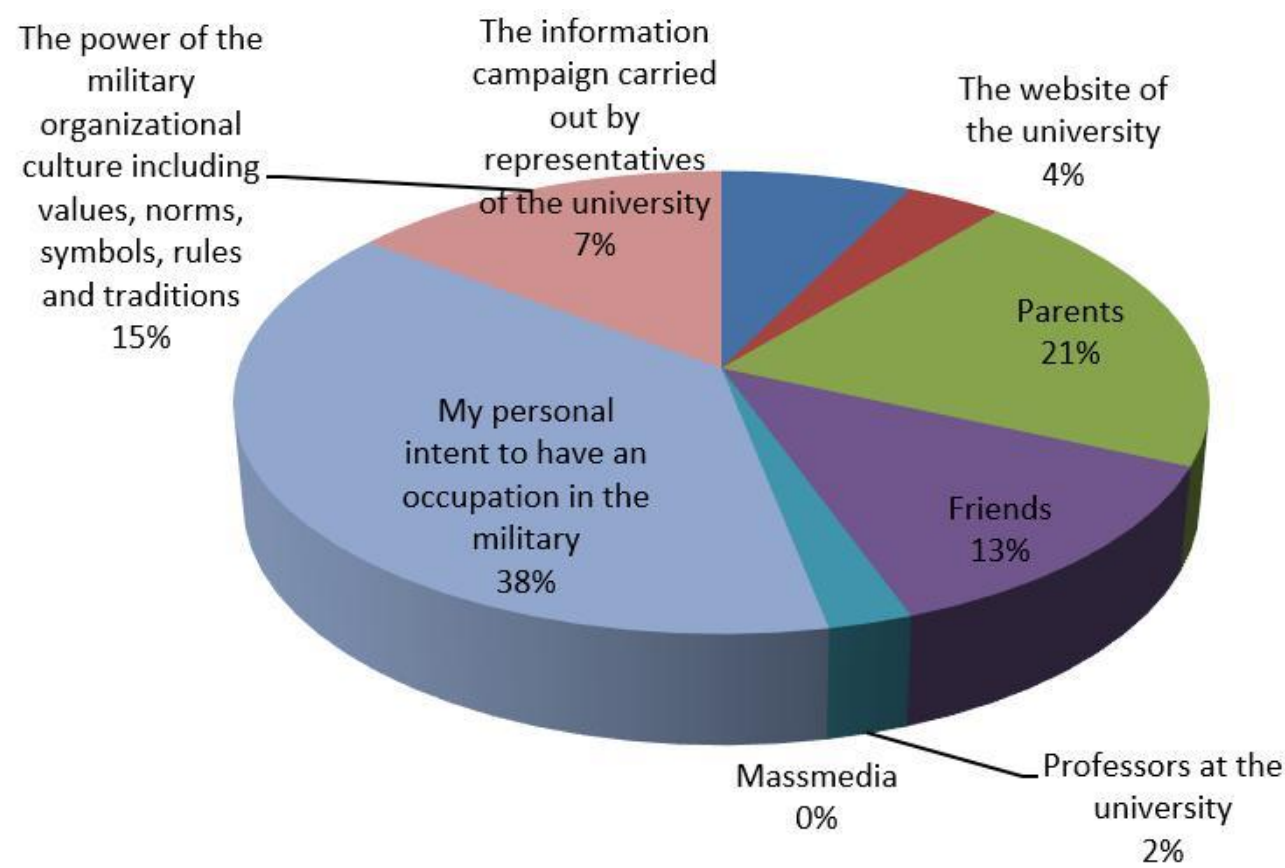

Fig. 1. What was your motivation for applying to the Vasil Levski National Military University? Source: own elaboration.

2. Where did you get information about the military specializations and civilian specialties offered at the National Military University?

- from the information campaign carried out by university representatives $-8 \%$

- from the university website- $42 \%$

- from parents $-15 \%$ 
- from friends $-25 \%$

- from university lecturers - 9\%

- from the media $-0 \%$

- the military district $-2 \%$.

The data analysis shows that the university website is the most significant source of information regarding the military specializations and civilian specialties offered at the National Military University, followed by information provided by friends.

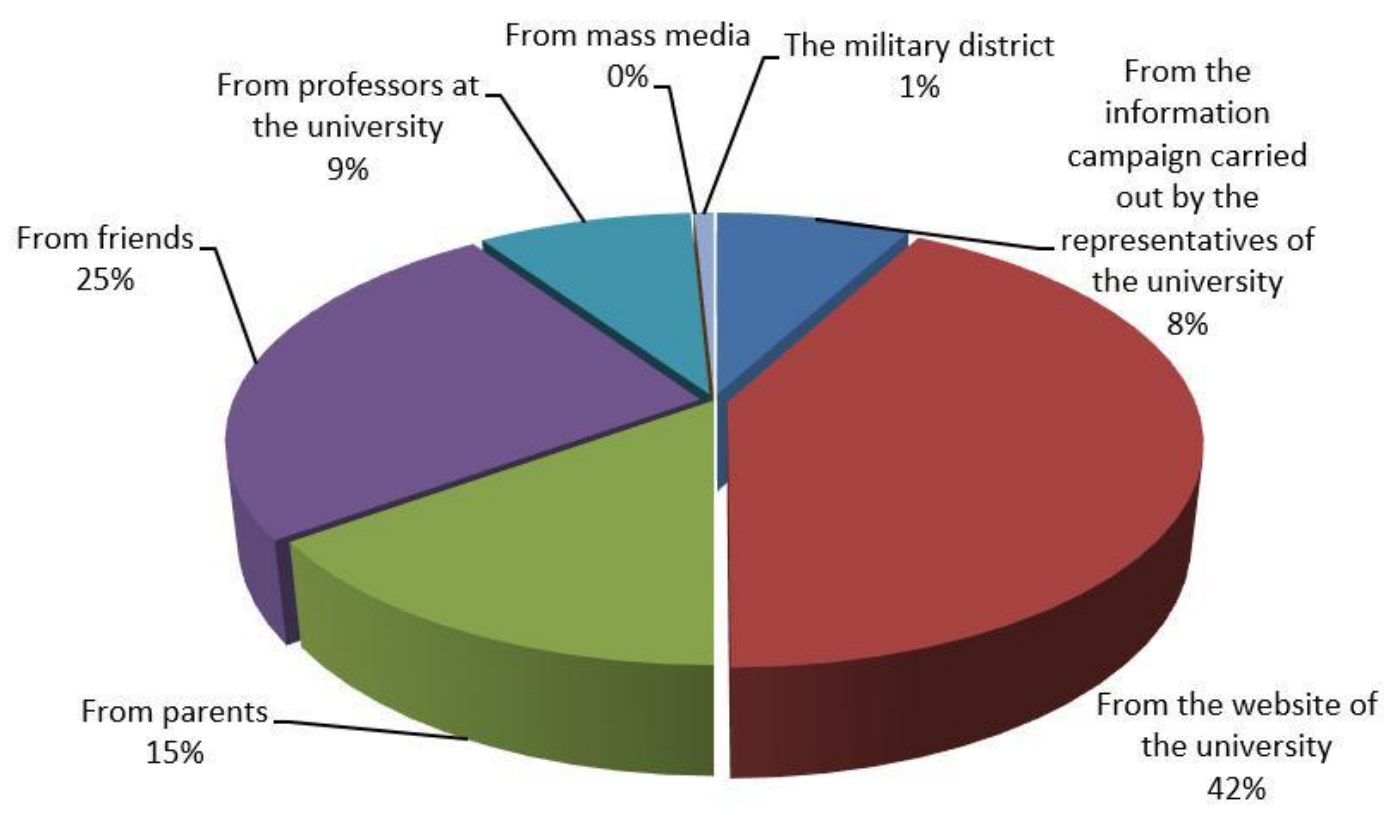

Fig. 2. Where did you get information about the military specializations and civilian specialties offered at the Vasil Levski National Military University?

Source: own elaboration.

3. How did you choose the specific military specialization you are currently studying?

- My choice was based on the information campaign carried out by university representatives $-9 \%$

- My choice was based on my parents' opinion - $20 \%$

- My choice was based on my friends' opinion - 20\%

- My choice was based on university lecturers' opinions - 9\%

- My choice was based on information provided by the media - $2 \%$

- Personal motivation $-40 \%$

The data analysis shows that the choice of the specific military specialization in which the trainees are currently involved was most strongly influenced by their personal motivation, followed by parents' and friends' opinion. 


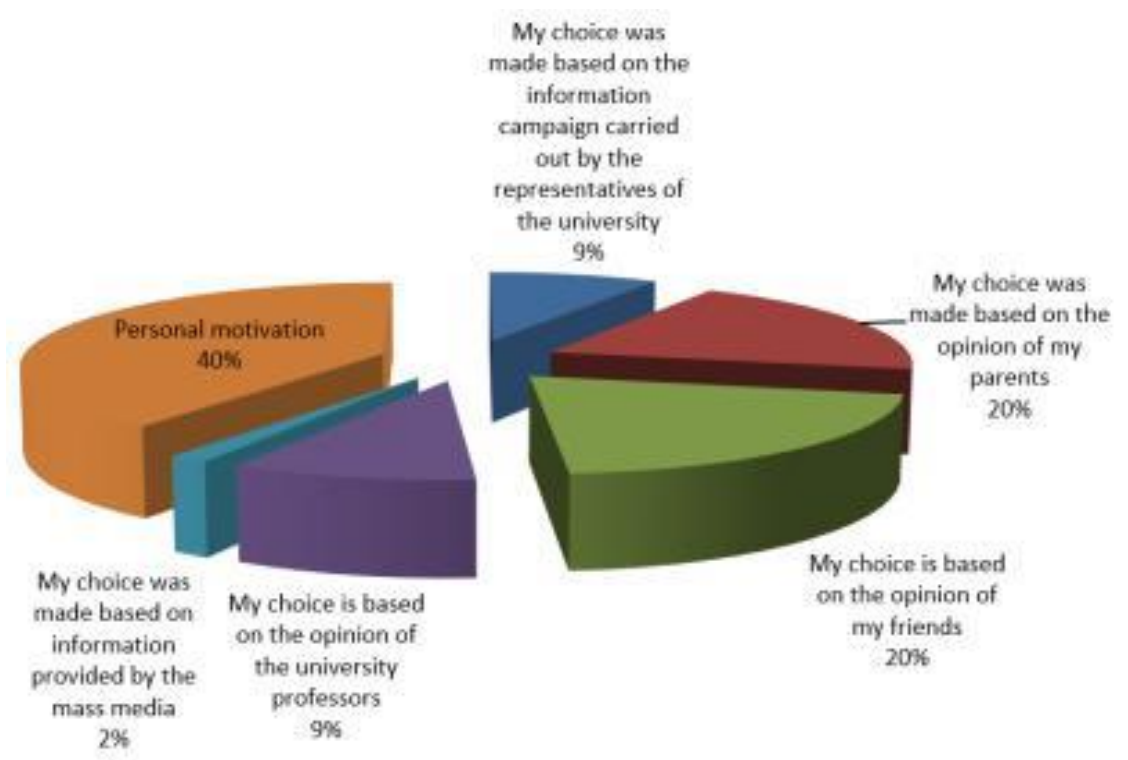

Fig. 3. How did you choose the specific military specialization you are currently studying?

Source: own elaboration

4. Was your decision to apply to the university influenced by the opinion of:

- Parents - 17\%

- Teachers $-1 \%$

- University lecturers - $1 \%$

- Friends - 13\%

- Family members - 10\%

- Personal desire $-58 \%$

The data analysis shows that the decision to apply to the university was most strongly influenced by trainees' personal desire and, to a lesser degree, by parents' and friends' opinion.

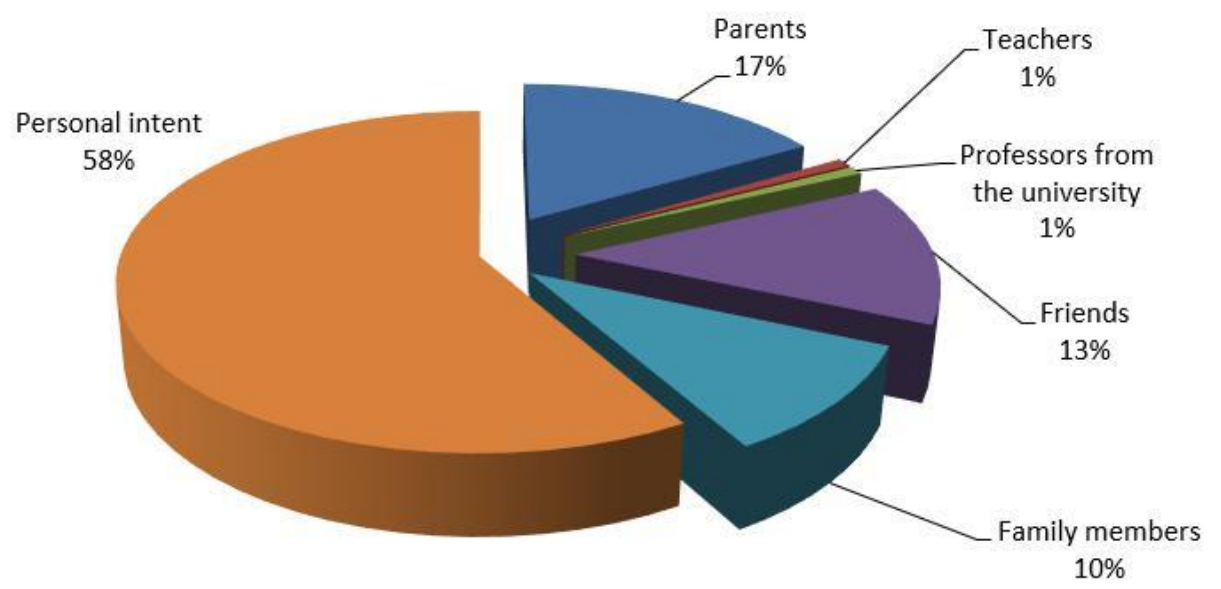

Fig.4. Whose opinion influenced your decision to apply to the university?

Source: own elaboration 
5. What other information channels would you recommend to be used in the future for getting better, timely, and reliable information about the applying process and training at the National Military University 'Vasil Levski’?

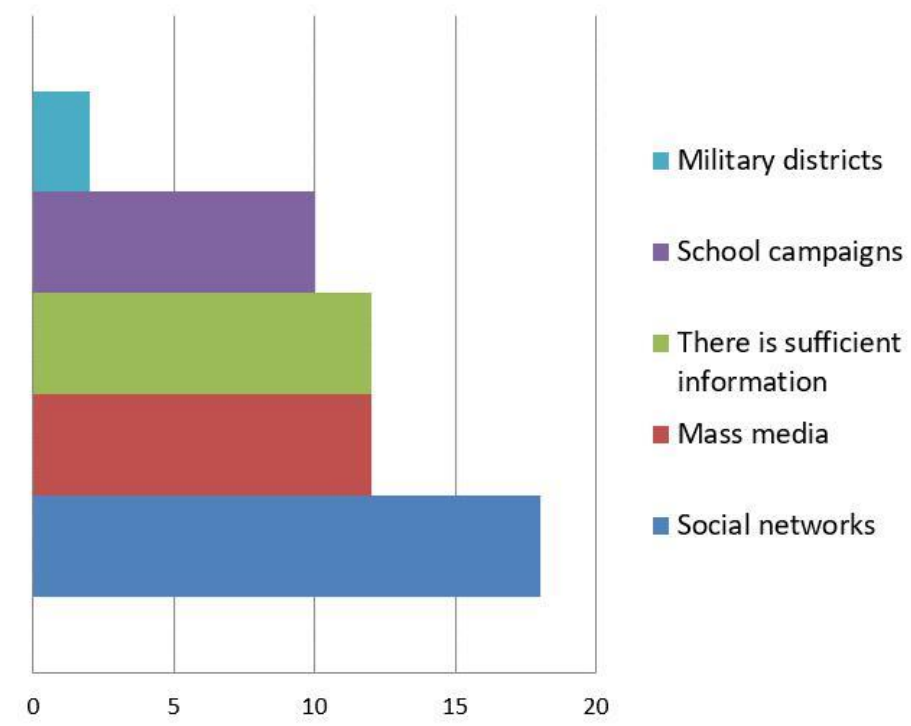

Fig. 5. What other information channels would you recommend to be used in the future for getting better, timely, and reliable information about the applying process and training at the Vasil Levski National Military University

Source: own elaboration

Information channels that trainees recommend to be used in the future for getting better, timely and reliable information about the applying process and training at the Vasil Levski National Military University are: social networks, media, and more information campaigns in schools.

6. What high school did you graduate from? (please write the full name of the school)

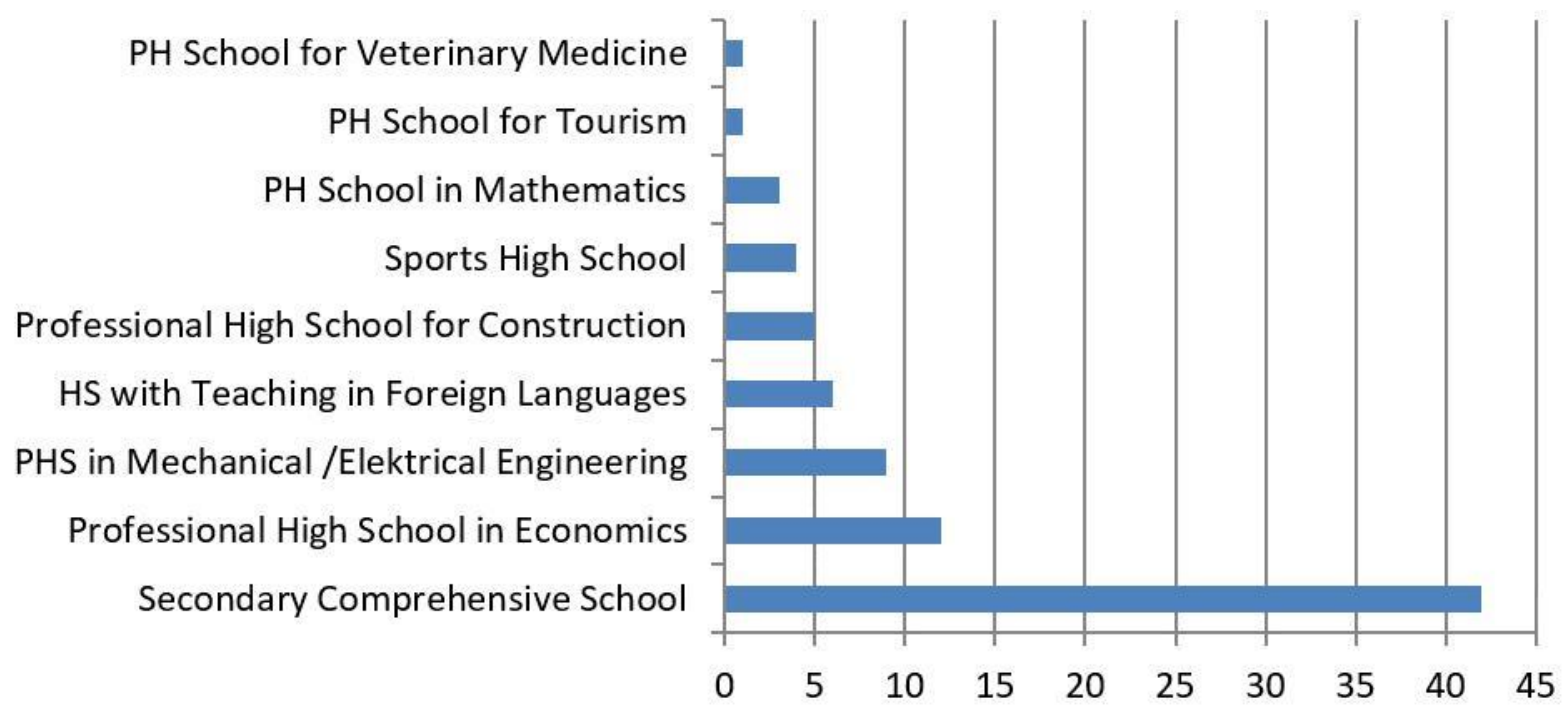

Fig. 6. What high school did you graduate from? (please write the full name of the school)

Source: own elaboration

The trainees in the Department of Security Logistics, Bachelor's degree program in the professional field of 'Military Affairs', speciality OUTPLO (Organization and management of 
tactical units for logistics) and civilian specialties in 'Economic Logistics' and 'Security Logistics' graduated mainly from secondary comprehensive schools, vocational high schools of economics and vocational high schools of mechanical and electrical engineering.

7. Where do you come from? (city, village)

The data analysis shows that the trainees at the Department of Security Logistics, Bachelor's degree program in the professional field of 'Military Affairs', speciality Organization and management of tactical units for logistics and civilian specialties in 'Economic Logistics' and 'Security Logistics' come mainly from the cities of Sliven, Lovech, Veliko Tarnovo, Yambol and Stara Zagora.

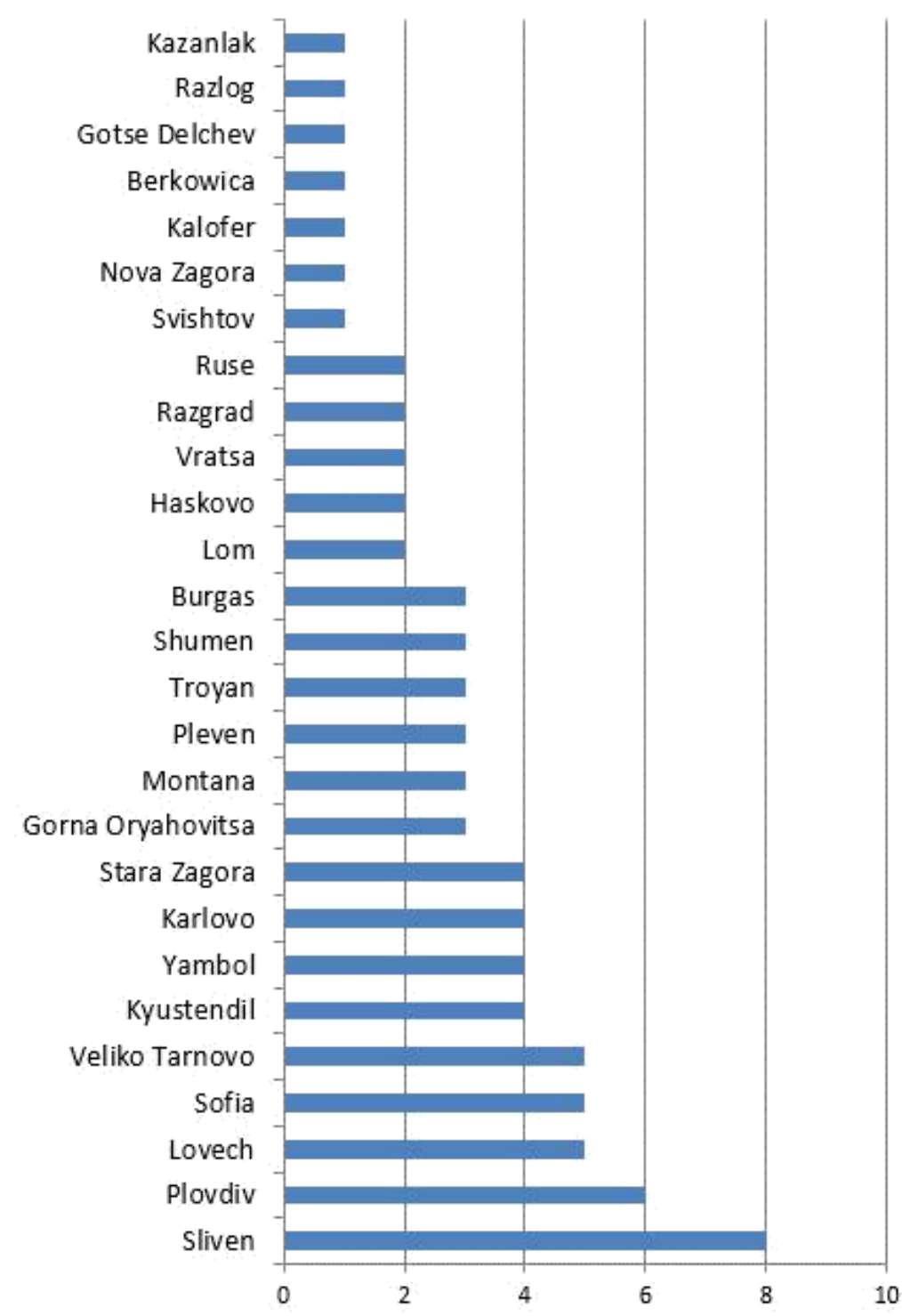

Fig. 7. Your city of residence

Source: own elaboration.

8. Do you have any problems learning the instructional material during the educational process? 


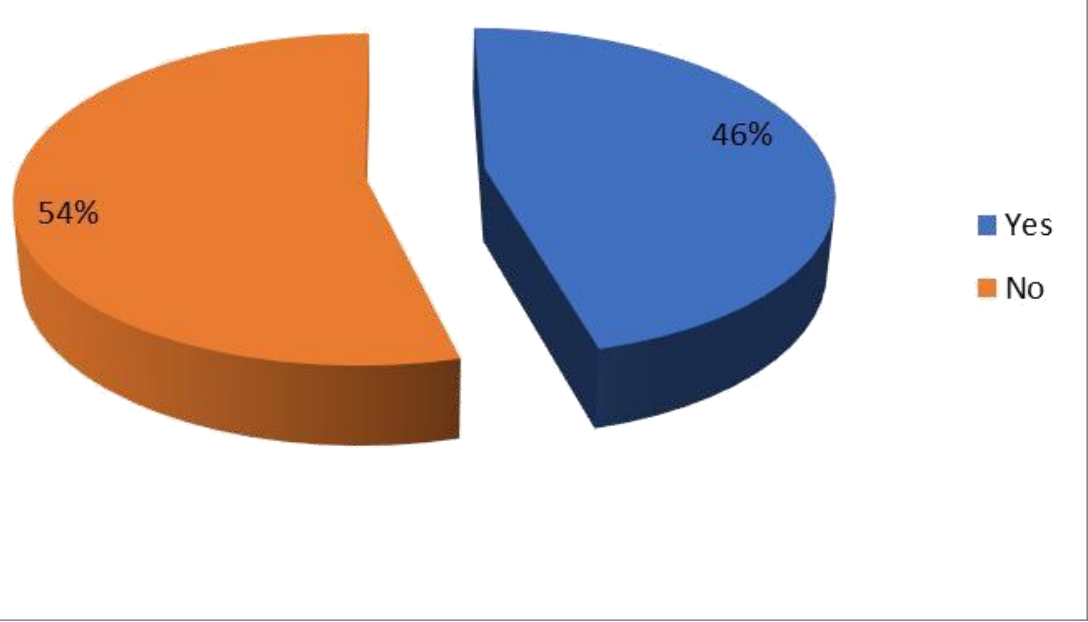

Fig. 8. Do you have any problems learning the instructional material during the educational process?

Source: own elaboration.

A significant part of the trainees mention that they have problems learning the instructional material during the educational process.

9. What were your cadet candidate examination marks?

Table 1. Cadet-candidate examination marks

\begin{tabular}{|c|c|}
\hline $\begin{array}{c}\text { Cadet-candidate } \\
\text { examination marks }\end{array}$ & Number of trainees \\
\hline over 30 & 21 \\
\hline 29 & 12 \\
\hline 28 & 22 \\
\hline 27 & 9 \\
\hline 26 & 10 \\
\hline 25 & 4 \\
\hline
\end{tabular}

Source: own elaboration.

The data analysis shows that the trainees of the Department of Security Logistics, Bachelor's degree program in the professional field of 'Military Affairs', speciality OUTPLO (Organization and management of tactical units for logistics) and civilian specialities

'Econimic Logistics' and 'Security Logistics' have very high cadet-candidate examination marks - over 28 points. 
10. What is your high school diploma Grade Point Average (GPA)?

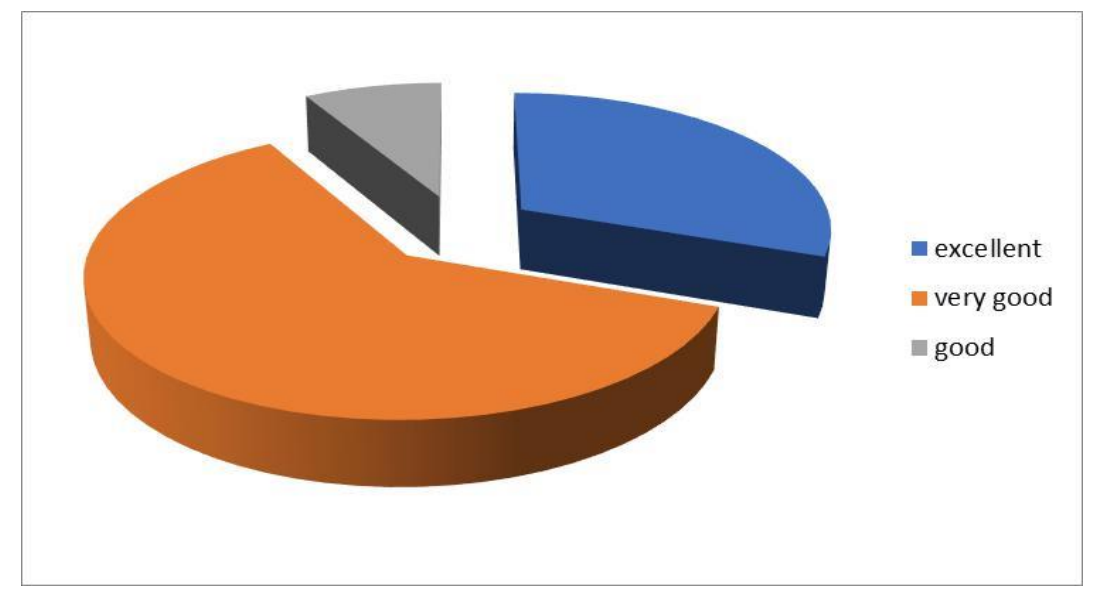

Fig. 9. What is your high school diploma GPA?

Source: own elaboration.

The data analysis shows that the trainees of the Department of Security Logistics, Bachelor's degree in the professional filed of 'Military Affairs', speciality Organization and management of tactical units for logistics and civilian specialities 'Econimic Logistics' and 'Security Logistics' have very high high-school GPA, namely excellent and very good.

11. What is your average household monthly income per person?

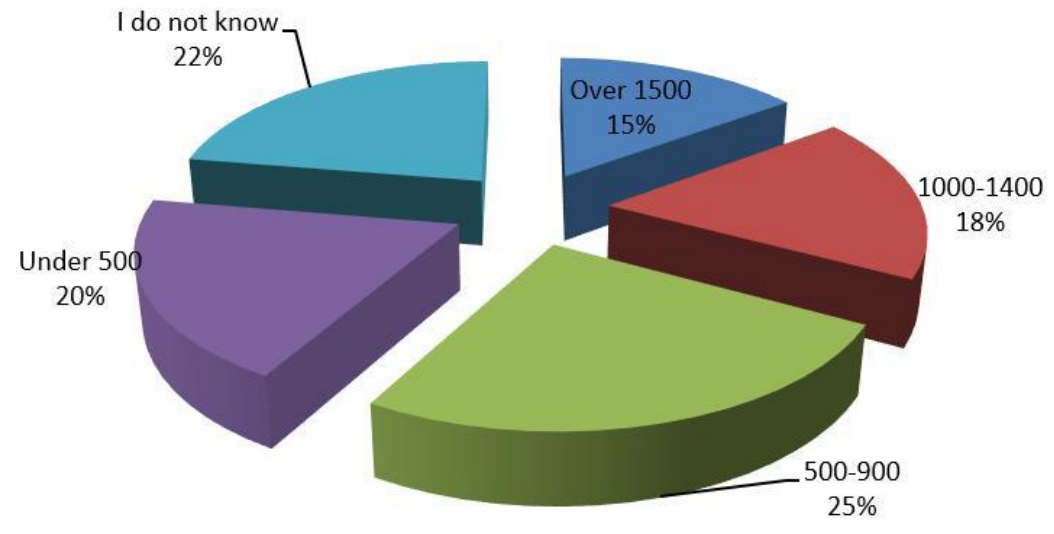

Fig. 10. What is your average household monthly income per person?

Source: own elaboration

The most common average household monthly income per person of the trainees in the department is in the amount of BGN 500-900. 
12. What is your parents' opinion about choosing the military profession?

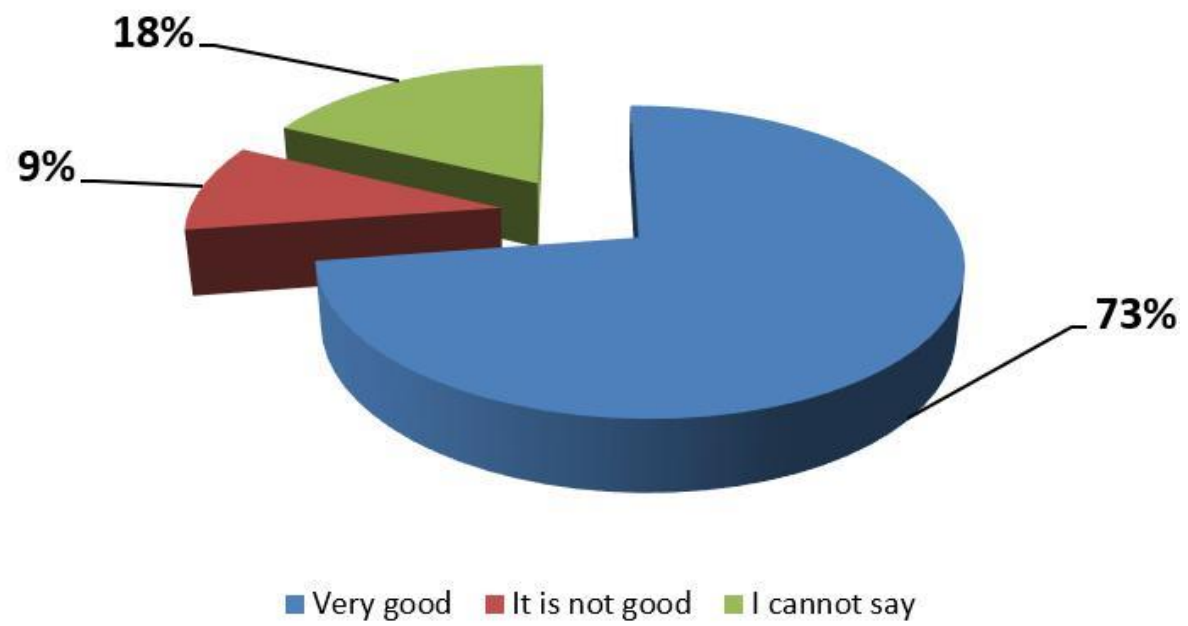

Fig. 11. What is your parents' opinion about choosing the military profession?

Source: own elaboration.

The opinion of trainees' parents about choosing the military profession is very positive.

\section{Conclusions}

Based on the survey, we can conclude that the department can direct its efforts to recruit future trainees mainly from secondary schools, vocational high schools of economics and vocational high schools of mechanical and electrical engineering, trainees from families with low- and middle-income, trainees with strong personal motivation to practise the military profession, trainees who achieve high results in their education. The information channels for accessing better, timely and reliable information about the applying process and training at the Vasil Levski National Military University should be expanded using social networks, media and more information campaigns in schools. To a large extent, parental opinion about trainees' choice of the military profession, also has an influence which was found to be very positive.

The initial database that determines the focus of this study in accordance with the objectives of the National Strategy of Scientific Research of the Republic of Bulgaria and the regional, national, and European priorities in the field of scientific research, Bulgarian and/or international legislation in the development of this work are: Republic of Bulgaria Defence and Armed Forces Act; Treaty on the Functioning of the European Union; Methodology in the Armed Forces, determining the logistics authorities' actions aimed at planning and providing the formations with material resources; Strategic Concept for the Defense and Security of the Members of the North Atlantic Treaty Organization; European Security 
Strategy; National Security Strategy of the Republic of Bulgaria; interoperability regulations and standards, orders, and other scientific publications and legal acts relevant to the research.

Based on the sources shown above and the survey, we can conclude that the department can direct its efforts to recruit future trainees mainly from secondary schools, vocational high schools of economics and vocational high schools of mechanical and electrical engineering, trainees from families with low- and middle-income, trainees with strong personal motivation to practise the military profession, trainees who achieve high results in their education. The information channels for accessing better, timely and reliable information about the applying process and training at the Vasil Levski National Military University should be expanded using social networks, media and more information campaigns in schools. To a large extent, parental opinion about trainees' choice of the military profession, also has an influence which was found to be very positive.

\section{References}

Atanasova-Krasteva, N. (2012) 'The educational process among the cadets and students of Vasil Levski National Military University - future leaders', Yearbook of Vasil Levski National Military University. Veliko Tarnovo, Bulgaria.

Doncheva, J. (2017) 'Challenges for young people before the Erasmus + European Program', Strategies of Educational and Scientific Policy, 6, pp. 593-599. ISSN 1314-8575.

Doncheva, J. (2014) 'National Strategy for Lifelong Learning (period 2014-2020)', Scientific Papers of the University of Ruse, 53(6.2). doi: 10.14807/ijmp.v11i4.1124.

Hysa, E. et al. (2020) 'Integrating teaching and learning in graduate studies: economic development course', Technology transfer: innovative solutions in Social Sciences and Humanities, pp. 61-64. doi: 10.21303/2613-5647.2020.001305.

Izadi, Z. D. et al. (2020) 'The evaluation of the impact of innovation management capability to organisational performance', Qualitative Market Research, 23(3), pp. 697-723. doi: 10.1108/QMR-04-2020-0052.

Manea Tonis Rocsana, B. et al. (2020) 'Woman political leadership in Romania versus other countries', Independent Journal of Management \& Production, 11(4), p. 1381. doi: 10.14807/ijmp.v11i4.1124.

Manolov, D. (2016) 'Possibilities of the situational approach in the training in security logistics', Conference proceedings of the Annual University Scientific Conference of the Vasil Levski National Military University. Veliko Tarnovo, Bulgaria.

Marinov, R. (2018) Dynamics in the Theory and Practice of the Strategic Management. International Conference on High Technology for Sustainable Development (HiTech), pp. 1-2, doi: 10.1109/HiTech.2018.8566527.

Petrova, E. (2015). 'Methodology on Study of Motivation for Education based on Opinions' Research of Cadets from Vasil Levski National Military University, Bulgaria', Socioeconomic Analysis Scientific Journal, 8 (2), pp. 127-133.

Ştefănescu, R. (2011) 'Leaders decided to change the world. Review Quality - Access to Success', Edited by Romanian Society for Quality Assurance - SRAC, 12, pp. 621-625. 
Stoykov, S. (2018) 'Scientific knowledge - source of a competitive advantage in security', International conference 2018 on High Technology for Sustainable Development (HiTECH). doi: 10.1109/HiTech.2018.8566548.

Tzvetkov, D. et al. (2015) 'Leadership style analysis in different categories of military personnel'. Conference proceedings of the III International Scientific and Technical Conference. Veliko Tarnovo. Bulgaria.

Varbanova, V. (2014) 'Possibilities for application of a modified model for increasing the efficiency of the admission and selection of cadets in the higher military schools', Conference proceedings of the scientific conference of the Vasil Levski National Military University. Veliko Tarnovo, Bulgaria.

Zegoicea, A. et al. (2013) 'Comparative Case Study Regarding Cadet's Motivation Methodology', Revista Academiei Fortel or Terestre, 18(3), pp. 301-307.

Zhekova, V. (2013) Women in the army. Review Gender equality in politics. The Bulgarian experience. Avangard Prima.

\section{Other documents:}

National Defense Strategy, Council of Ministers, Ministry of Defense of the Republic of Bulgaria, Sofia, 2016.

Methodology for monitoring of the classes held at the Vasil Levski National Military University, Veliko Tarnovo, 2004.

Regulations for admission and study activities at the Vasil Levski National Military University, adopted with a protocol No. 33 от 31.3.2009, amended and supplemented with a protocol No. 54/24.01.2011, No. 59/19.07.2011 and No. 66/28.02.2012, No. 69/29.05.2012 and No. 79/24.04.2013) of the Academic Council, Vasil Levski NMU Publishing, 2013.

Regulations for application of the Republic of Bulgaria Defence and Armed Forces Act, promulgated SG No. 25/30.3.2010, amended and supplemented SG No.107/28.12.2018.

Strategy for development of the system for education and qualification of the personnel servicemen of the Armed Forces of the Republic of Bulgaria, 2006.

Updated National Security Strategy of the Republic of Bulgaria, adopted by decision of the National Assembly of March 14, 2018, prom. 26 of 23.03.2018.

White Paper on Defense and Armed Forces of the Republic of Bulgaria, decision of the 41st National Assembly in October 2010. 